\title{
The Change of Former Female Migrants Lifestyle in Sragen Indonesia
}

\author{
Ratih Rahmawati \\ Faculty of Social and Political Sciences \\ Universitas Sebelas Maret \\ Surakarta, Indonesia \\ ratih013@student.uns.ac.id
}

\author{
Argyo Demartoto* and R. B. Soemanto \\ Department of Sociology \\ Universitas Sebelas Maret \\ Surakarta, Indonesia \\ *argyodemartoto_fisip@staff.uns.ac.id
}

\begin{abstract}
Former Female Migrants are identical with less skilled workers having minimum knowledge and skill thereby relying on only remittance to fulfil their life need. This research aimed to find out the change of former female migrants' lifestyle in Sragen, Indonesia, analyzed using Garner's social change theory. This qualitative research with case study approach processed the data in-depth and comprehensively through observation, interview, and documentation. The result of research showed that former female migrants used remittance excessively until it is used up rather than used it as business capital. Originally, it could improve their family economy, but after they come back home, they should adapt to environment in their origin area in which husband relies for their life on their wife's income when they become migrants, children begins to need more attention from a mother, and household need increases. For the sake of their and family's life former female migrant takes a strategy to enable them to maintain their family wellbeing just like that when they became migrants. The strategy taken by former female migrants is to utilize their remittance optimally for business capital and creating a social network containing productive activities that can increase their income. The activity is conducted in group, including goat breeding, food catering, vegetable-processed food, and handicraft production. Former migrant women who have a business group had equal rights in employment so as to have a lifestyle change was effected in the former migrant women. Their rights when productive activities were carried out because it can access knowledge, information, and capital assistance.
\end{abstract}

Keywords - lifestyle; social change; a former migrant women

\section{INTRODUCTION}

Former migrant women who came back to their origin area find difficulty in seeking job in formal sector, because of their limited skill and knowledge, and only Elementary School or Junior High School certificate they have. They are helpless and not independent with income different from that when the became migrant $[1,2]$. The number of former migrant women with productive business in Mojorejo, Sragen, Indonesia is 65 $(27.31 \%)$, while that without productive business is 173 $(72.68 \%)$ in 2015 . They are in dilemmatic position: on the one hand, they do not want to work again as migrants but when they come back home, they find difficulty in seeking job corresponding to their ability [3-5].
Meanwhile, former migrant women becomes family backbone because their husbands have no job, thereby needing productive activity to support daily needs [6-8]. To achieve the $5^{\text {th }}$ goal of Sustainable Development Goals (SDG's), Gender Equality and Women and Female Adolescent Empowerment, an empowerment program is required to make men and women powerful by having productive activity. Those having productive activity will be independent and family support [911]. Former migrant women have equal right to get job like men, thereby can make them and their family prosperous [1214]. Article 5 of Republic of Indonesia's Law Number 13 of 2003 about Manpower mentions that every worker has equal opportunity of getting job without discrimination.

However, the condition becomes difficult when former migrant women coming back to their origin area find difficulty in adapting to their current condition and have consumptive behavior. Remittance they get when they become migrants is used up when they come back to their origin area, because they use it to buy high-price needs such as house, land, farm, motor vehicle, cow, electronic appliances, and etc. Only few of them use it for business capital $[13,15,16]$. For that reason, a movement is required to change their habit jointly [17-19].

Migrant workers exist in every region in Indonesia, one of which is Sragen, Indonesia. Organization protecting them is Indonesian Migrant Family Organization (Indonesian: Keluarga Migran Indonesia or KAMI) Mukti having empowerment program and serving as an organization accommodating former migrant men and women to get equal right in the term of productive business supply and ownership, useful to give spirit and to motivate its members to have productive activity, to be independent and powerful. In addition, it can provide new job opportunity to surrounding people, thereby resulting in social change in community members [20-22].

Social change affects individual's awareness level, thereby doing something impacting on positive change occurring inside them [23]. Social change conducted by former migrant women can occur when they conduct productive activity in an organization like migrant worker organization, because they can assemble with their fellow former migrants having same fate, and briefing will be given to avoid consumptive behavior. In addition, individual can change because the structure where he/she is in will create an individual's behavior. This research 
aimed to find out the change of former female migrants' lifestyle in Sragen, Indonesia, analyzed using Garner's social change theory.

\section{METHOD}

This research was taken place in Sragen Indonesia from January to May 2017. Case study approach in this qualitative approach explains uniqueness and typicality of former migrant empowerment [24]. The subject of research consisted of administrators and members of migrant worker organization, and Sragen Labor Service. To validate the data, method and data source triangulation techniques were used. Data analysis was conducted using typology, representing and classifying data in detail by pattern in order to be meaningful, so that it can be analyzed and understood [25].

\section{RESULT AND DISCUSSION}

Migrant worker organization accommodates male and female migrants, gives them an opportunity of increasing knowledge and skill to establish new business. KAMI Mukti in Sragen is the organization aiming to empower former migrants coming back to their origin area to prevent them from going back to work abroad. The members of KAMI Mukti organization consist of 40 persons. Sragen is the Regency in Java Island with the largest number of its people working as migrants. The chairperson of KAMI Mukti said Organization (thereafter called the Organization) that only few former migrant women join the Organization as it is considered as wasting time, and it is better to take care of their children and husband or to go to farm than to join the association.

This organization has such activities as recruiting members for member and administrator regeneration, and training or briefing such as training for producing chips, cake, and accessories. The training has established a business group facilitated by the organization in collaboration with related institution. In addition, there is cattle grant for the members of organization. Meanwhile, socialization is also conducted to reinforce the former migrant women in order to be independent in collaboration with Labor Service, Small- and Medium-scale Enterprises and etc. The presence of productive activity can change the former migrant women behavior from consumptive into more productive one.

Consumptive behavior of former migrant women is to use up remittance by purchasing luxurious product thereby they have no adequate capital for business. However, those products will be resold when their daily need is not fulfilled. In the presence of KAMI Mukti organization, the former migrant women is given training in order not to use up remittance but to save it and to use some of it for business capital. A member of organization said that her and her family's welfare level improves after she participate in productive activity and join vegetable chip producing group business actively. The income of former migrant women can be used to help their husband and to buy children's school necessities.

The staff of Sragen Labor Service said that binding the self to an organization will enable the former migrant women to get capital grant from government. They will acquire entrepreneurial information easily including the knowledge to embark on or to expand business, and additional income from business ran in group. KAMI Mukti Organization also fights for the workers' rights so that in its implementation there is no discrimination against former migrant men and women in the term of capital and knowledge receiving. Former migrant women have equal right to the men in making decision. Informant said that in organization meeting, they can also express aspiration, suggestion, and critique for the sake of mutual interest. The Secretary of Organization, Mrs. NS, often lead the routine meeting. Participating in empowerment program in KAMI Mukti Organization can benefit their members, because it can change their mindset and behavior into the productive ones with the initial objective of working for their and their family's wellbeing.

Former migrant women do not want to work as migrant again as it is replete with risks such as unpaid wage or violence befalling them. They want to stay and to seek job in their own area. However, majority former migrant women coming back home usually have habit adverse to themselves, consumptive behavior and not focusing on having their own job [26]. Former migrant women aware of the need for making themselves and their family prosperous will make change, improve their and their family's wellbeing by no longer behaving consumptively, expand networking, think of creating job opportunity, and not rely on remittance. The change made by former migrant women can affect themselves and even wide society, because business can make them powerful and independent, and improve the condition of surrounding community [27].

KAMI Mukti organization builds social network, thereby becoming a place to share spirit in pioneering a job opportunity. Empowerment program in it is conducted in group, meaning it can accept and empower the former migrant women to be its members. Those who come back to Indonesia can establish new business, have income and be closer to their family. This presence of organization can create job opportunity thereby reducing unemployment rate among the people surrounding [16]. Socialization and training activities can give former migrant women a productive activity thereby changing their mindset in daily life. The organization's activities give its members spirit of establishing and running new business and creating network to bring about the change inside individual [2].

They socialize and exchange idea or input for the collective progress. Thereafter, participating in organization activity will maintain silaturahim bond, reduce unemployment rate, and increase knowledge and insight into entrepreneurship thereby improving the family wellbeing and economy in Sragen, Indonesia. There is no different relationship between female and male members of organization; there is equality in accessing information and capital. Former migrant women participate maximally in organizational activity, have equal right to the men, and no compulsion from any party in running entrepreneurship activity [13,18,27]. In establishing group business, they also have equal right in implementing joint activity without discrimination, thereby having an opportunity of implementing development in order to be independent and powerful and abandoning their adverse behavior [28]. 


\section{CONCLUSION}

Former migrant women participating active in organization are aware of the importance of improving their and their family's wellbeing, so that they attend training activity for their productive business. Their right to conduct productive activity can be met, because they can access knowledge, information and capital grant. There is a change inside former migrant women from consumptive behavior into productive one, thereby can benefit themselves and establish new job opportunity for surrounding people.

\section{REFERENCES}

[1] Jenkins, K. Women, mining and development: An emerging research agenda. The Extractive Industries and Society, 12, 329-339. 2014.

[2] Zang, B., Lv, P., \& Warren, C. M. J. Housing prices , rural e urban migrants $\hat{\mathrm{a}} \mathrm{TM}$ settlement decisions and their regional differences in China *. Habitat International, 50, 149-159. 2015.

[3] Christou, A., \& Michail, D. Migrating motherhood and gendering exile: Eastern European women narrate migrancy and homing. Women's Studies International Forum, 52, 71-81. 2015.

[4] González-González, J. M., Bretones, F. D., Zarco, V., \& Rodríguez, A. Women, immigration and entrepreneurship in Spain: A confluence of debates in the face of a complex reality. Women's Studies International Forum, 345, 360-370. 2011

[5] Hosoe, N. Impact of border barriers, returning migrants, and trade diversion in Brexit: Firm exit and loss of variety. Economic Modelling, September. 2017.

[6] Beşpinar, F. U. Questioning agency and empowerment: Women's workrelated strategies and social class in urban Turkey. Women's Studies International Forum, 336, 523-532. 2010.

[7] Démurger, S., \& Xu, H. Return Migrants: The Rise of New Entrepreneurs in Rural China. World Development, 3910, 1847-1861. 2011

[8] Liu, X., Gao, L., Lu, J., \& Wei, Y. The role of highly skilled migrants in the process of inter-firm knowledge transfer across borders. Journal of World Business, 501, 56-68. 2015.

[9] Allwood, G. Gender mainstreaming and policy coherence for development: Unintended gender consequences and EU policy. Women's Studies International Forum, 39, 42-52. 2013.

[10] Magnani, E., \& Zhu, R. Gender wage differentials among rural-urban migrants in China. Regional Science and Urban Economics, 425, 779793. 2012.

[11] Tufuor, T., Niehof, A., Sato, C., \& van der Horst, H. Extending the moral economy beyond households: Gendered livelihood strategies of single migrant women in Accra, Ghana. Women's Studies International Forum, 50, 20-29. 2015.

[12] Lulle, A. Shifting notions of gendered care and neoliberal motherhood: From the lives of Latvian migrant women in Guernsey. Women's Studies International Forum, 47PB, 239-249. 2014.

[13] Wilbur, A. Back-to-the-house? Gender, domesticity and disempowerment among back-to-the-land migrants in northern italy. Journal of Rural Studies, 35, 1-10. 2014.

[14] Waltz, A. The women who feed us: Gender empowerment or lack thereof in rural Southern Brazil. Journal of Rural Studies, 47, 31-40. 2016.

[15] Hanhörster, H., \& Weck, S. Cross-local ties to migrant neighborhoods: The resource transfers of out-migrating Turkish middle-class households. Cities, 59, 193-199. 2016

[16] Waddell, B. J., \& Fontenla, M. The Mexican Dream? The effect of return migrants on hometown development. Social Science Journal, 523, 386-396. 2015.

[17] Naumburg, E. H., \& Hepworth, J. Review of Feminist Family Therapy: Empowerment in Social Context. Families, Systems, \& Health, 221, 127-129. 2004

[18] Murphy-Graham, E. Opening Minds, Improving Lives: Education and Women's Empowerment in Honduras Vol. 1. 2012.

[19] Al-Dajani, H., \& Marlow, S. Empowerment and entrepreneurship: a theoretical framework. International Journal of Entrepreneurial Behavior \& Research, 195, 503-524. 2013.

[20] Germano, R. Migrants' remittances and economic voting in the Mexican countryside. Electoral Studies, 324, 875-885. 2013.

[21] Joseph, C. Renegotiating cultural and work identities pre and postmigration: Malaysian migrant women in Australia. Women's Studies International Forum, 36, 27-36. 2013.

[22] Chauvet, L., \& Mercier, M. Do return migrants transfer political norms to their origin country? Evidence from Mali. Journal of Comparative Economics, 423, 630-651. 2014

[23] Garner, Roberta Ash. Social Change. Chicago: Rand Mc Nally College Publishing Company. 1977.

[24] Yin, R. K. Case Study Research. Design and Methods. Sage, 44, 264 267. 2009.

[25] Patton, M. Qualitative Evaluation and Research Methods. Qualitative Evaluation and Research Methods, 1990

[26] Killian, C., Olmsted, J., \& Doyle, A. Motivated migrants: Reframing Arab women's experiences. Women's Studies International Forum, 356, 432-446. 2012

[27] Kuschminder, K. Female Return Migration and Reintegration Strategies in Ethiopia. 2013.

[28] Rydzik, A., Pritchard, A., Morgan, N., \& Sedgley, D. Humanising migrant women's work. Annals of Tourism Research, 64, 13-23. 2017. 